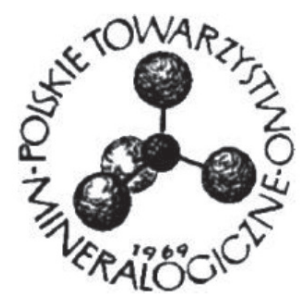

\title{
Mineralogical studies of the Maastrichtian Gerinya Claystone of the Patti Formation, southern Bida Basin, Nigeria: Implication for industrial application
}

\author{
Oluwaseye P. Oyetade ${ }^{1 *}$ \\ Charles I. Konwea ${ }^{2}$ \\ Olusola J. Ojo ${ }^{3}$ \\ Tayelolu M. Odesanmi ${ }^{4}$
}

${ }^{1}$ Department of Geology, University of Calabar, Calabar, Cross River, Nigeria.

${ }^{2}$ Department of Geology, Obafemi Awolowo University, lle Ife, Osun State, Nigeria.

${ }^{3}$ Department of Geology, Federal University Oye-Ekiti, Ekiti State, Nigeria.

${ }^{4}$ School of Public Health, University of Medical Science, Ondo State, Nigeria

*Corresponding author: oyetadeoluwaseye@gmail.com; oyetadeop@unical.edu.ng

\begin{abstract}
The mineralogical compositions of the Gerinya claystone, Patti Formation, Southern Bida Basin, Nigeria, were investigated to infer their sedimentological process and industrial application. Mineralogical analysis of the claystone was carried out using the X-ray diffraction (XRD) method. The diffractogram peaks aided the identification of the clay and non-clay minerals in the study area. The XRD showed kaolinite as the major clay mineral with compositions ranging from $10.8-67.6$ wt\%. The non-clay minerals were quartz, anatase, diopside, goethite, hematite, rutile, muscovite and microcline. Among the non-clay minerals, quartz had the highest percentage mineralogical composition of 21.2 to $83.4 \mathrm{wt} \%$. The mineral assemblage is typical of a hot and humid climate where chemical alteration and hydrolysis of silicate minerals are severe. The sediments are of mafic and felsic crystalline rocks origin. The sediments are of low energy floodplain/interchannel depositional environment. The Gerinya claystone vary from low to high porosity and very low to low permeability. The claystone can be used as clay liners and as raw material for ceramic production. The application of the claystones in fertiliser production will require some processing. The claystone can be used for haemorrhage control in the pharmacological/medical sector. Although, the ingestion of the claystones could lead to dental damage and possible perforation of the sigmoid colon in the gastrointestinal tract.
\end{abstract}

Keywords: Gerinya, X-Ray Diffraction (XRD), diffractograms, claystone, Patti Formation

\section{Introduction}

Clay can be used as a particle size and rock terms. In terms of particle size, the Wentworth scale defines clay as any sediment finer than $0.0039 \mathrm{~mm}$ (Wentworth, 1922). However, clay as a rock is defined as fine-grain sediments that become plastic and tenacious when moist/damped, and upon being baked or fired, it becomes permanently hard/firm (Velde, 1992 and 1995). Clay rocks are composed of single/mixed layered clay minerals (illite, kaolinite, montmorillonite) with other minerals (quartz, muscovite, carbonate and metal oxides) that are of clay-sized crystals. Clay minerals are formed from chemical weathering of pre-existing crystalline rocks, during burial diagenesis (Hower et al., 1976; Aldega et al., 2017 and 2018) and are rich in feldspar (Velde and Meunier, 2008). Clay minerals formed from chemical weathering are predominant in the warm tropical and sub-tropical regions of the world. Clay minerals can also be formed as a product of hydrothermal 
alteration (Cox and Brown, 1998; Corrado et al., 2014). Chemical weathering has been noted to be the predominant geological process that affects clay composition and clay-rich sediments, although the pre-existing rocks are altered into soils and clays by combining effects of biological, chemical and physical weathering activities (Nesbitt and Young, 1989; Singh, 2009).

Furthermore, these clay minerals (illite, kaolinite, montmorillonite) have been discovered to be useful within the industries as the major raw material in the production of ceramic, paint, paper, refractory, plaster of Paris and pharmaceutical products used in the cure of ulcers, dysentery and cholera, detoxification, adsorption and skin emulsifiers (Mpuchane et al., 2008). They are also used as filling materials in construction works and as a major constituent in fertiliser production.

Sediments rich in clay minerals occur as weathered regolith above basement rocks, especially where the rocks are rich in silicate minerals; or as materials carried into depositional basins during erosional activities. The Bida Basin (Fig. 1a) is one of the sedimentary basins in Nigeria characterised by the deposition of sediments. The Bida Basin is further subdivided into two: Northern and Southern Sub-Basins. The Southern Sub-Basin or Southern Bida Basin is made up of three formations: Lokoja Formation, Patti Formation and Agbaja Formation (Obaje, 2009). Claystone is a major component of these formations and has been found useful in agriculture, pharmaceutical and food processing companies.
Although there have been a number of studies in the Southern Bida Basin, the inorganic claystone deposits of Gerinya, Patti Formation have not been fully explored by researchers. Most of the past studies focused on the organic clays (shales) and their hydrocarbon potentials in the basin (Akande et al., 2005; Ojo and Akande, 2009). In Gerinya, southern Bida Basin, where this study was conducted, only the work of Olabode (2016), on soft-sediment deformation structures has been documented. Therefore, this study is aimed at providing the mineralogical compositions of the stratigraphic claystones exposure of the Patti Formation Gerinya, southern Bida Basin, since the mineralogical composition of a rock is critical to its behaviour and application. Considering the classification of clay mineral groups (kaolin, smectite, illite, and chlorite), the mineralogy examination of the claystones is useful in determining their suitability for different applications. The world kaolin (kaolinite, dickite, nacrite and halloysite) market size was estimated at 4.76 billion USD in 2019 and it is expected to grow exponentially at the rate of 3.5\% from 2020 to 2027. The demand for clay minerals as raw materials in paper, ceramics, paint and coatings, fibreglass, plastic, rubber, cosmetics, pharmaceutical and medical applications are probably going to arise as a compelling variable for the business development over the conjecture time frame (Grand view research, 2020). Nigeria has several industries that can make use of these readily available and cheap clay minerals as raw materials. Despite the grow-

a)

b)

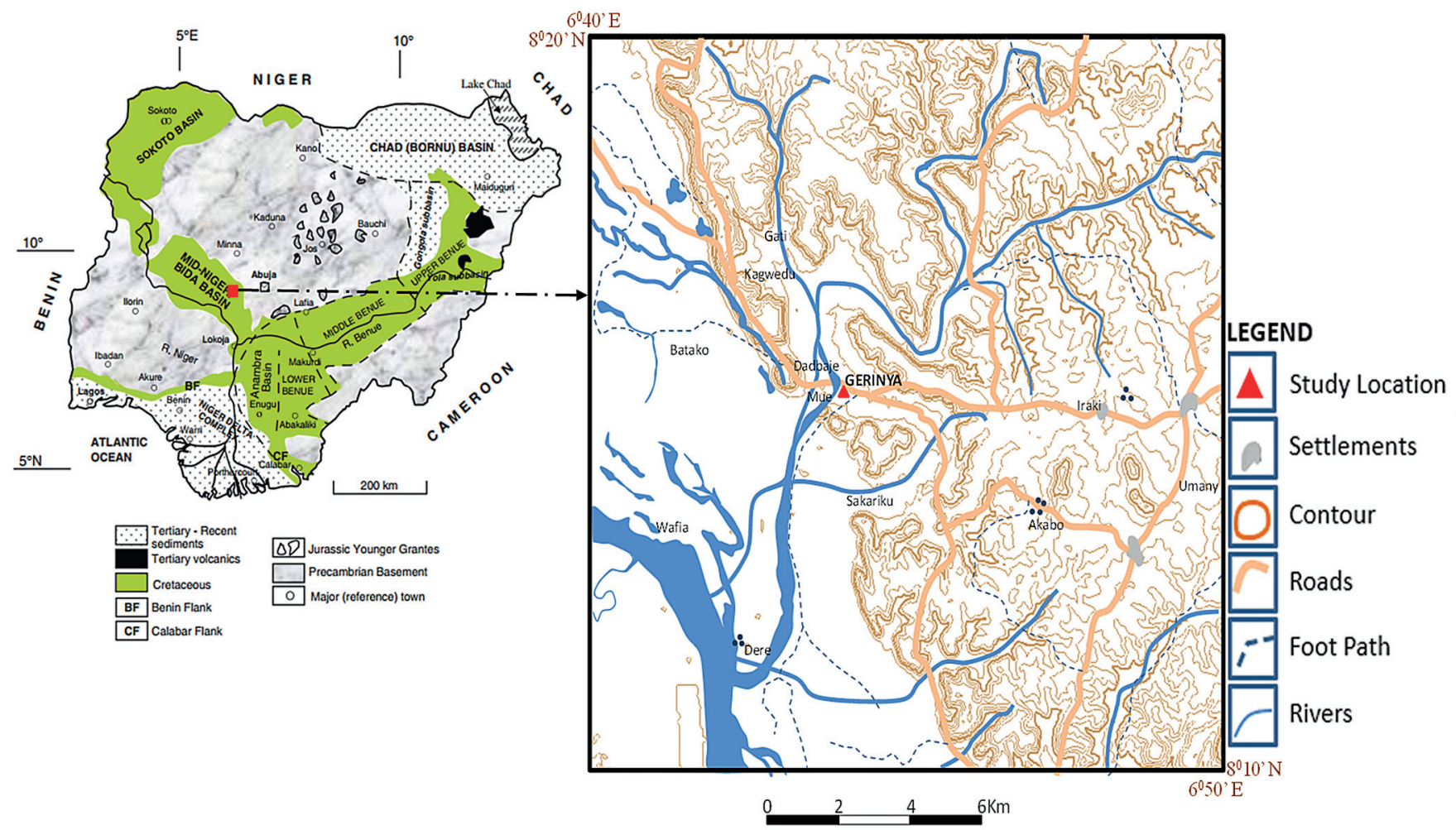

Figure 1. (a) Geological map of Nigeria showing the position of the Bida Basin (modified after Obaje 2009). (b) Map of the study area and location of the investigated outcrops. 
ing demands for clay minerals, with the possibility of creating jobs and alternative source of revenue for the government, most claystone deposits are yet to be fully explored. However, in order to improve the industrial utilization of clay minerals of Nigeria by local and foreign industries, there is need to assess the claystones' mineralogy for proper characterization of the claystones, hence this study.

\section{Study area and geology of the Bida Basin}

\subsection{Study Area}

The study area is located within the southern Bida Basin around Lokoja, Kogi State, Nigeria (Fig. 1a). The study area represents parts of the Patti Formation stratigraphic units in the southern Bida Basin. The geographic coordinates of the section under study are Latitude: $\mathrm{N}^{\circ} 8^{\circ}$ 14' 44.2" and Longitude: E006 ${ }^{\circ} 45^{\prime}$ 54.9' (Fig. 1a and b).

\subsection{Geological Settings}

The Bida Basin is also referred to as the Mid-Niger Basin or the Nupe Basin. The Bida Basin extends from Kontagora to Lokoja in Nigeria, as northwest-southeast trending intracratonic sedimentary basin (Obaje, 2009). The stratigraphic succession of the Bida Basin is made up of Upper Cretaceous sedimentary rocks (Fig. 2). These rocks were deposited as a product of basement fragmentation, block faulting and subsidence as well as rifting and drifting trending north-west, consequential to the Cretaceous opening of the South Atlantic Ocean.

The basin has four discrete/distinct and mappable stratigraphic units; the Bida Sandstone which is further subdivided into the Doko Member and the Jika Member, the Sakpe Ironstone, the Enagi Siltstone, and the Batati Formation (Fig. 2).

The southern Basin/ Sub-Basin is made up of three distinct and mappable formations; Lokoja Formation, Patti
Formation and Agbaja Formation. Outcrop of the oldest formation (Lokoja Formation) consisting of sandstones and conglomerates was observed to directly overlie the Pre-Cambrian to Lower Paleozoic basement gneisses and schists. The sandstones and conglomerates of the Lokoja Formation in the Koton-Karfi and Abaji areas are succussed by the Patti Formation which consists of alternating sequences of shales, siltstones, claystones and sandstones. These alternating sequences now evolved into the Agbaja Formation which comprise of claystones, concretionary siltstones and ironstones.

\section{Methodology}

The methodology adopted for this study involved both field work and laboratory analysis. The field work involved lithologic description and sample collection. The outcrop profiles were observed and described based on their colour, texture, thickness and sedimentary structures. Eight (8) fresh and representative claystone samples (GER 1C, 1D, 1G, 1J, 1L, 1Q, 1S and 1U) were collected during the field exercise for this study.

Hydrometer methods were used to study the particle size distribution of the samples, hydrometer analysis is a widely used method of obtaining an estimate of the distribution of soil particles sized from $0.075 \mathrm{~m}$ sieve to around $0.001 \mathrm{~mm}$.

A quantitative determination of the mineralogical compositions of the eight claystone samples was performed using X-ray diffraction (XRD) at the University of Pretoria, South Africa. The claystone samples were prepared for XRD analysis using a backloading preparation method. The claystone samples were mounted on sample holders with little pressure, using a blade to minimise the preferred alignment of the phyllosilicate minerals. The samples were scanned from 0 to $70^{\circ} 2 \theta$ (theta) at a counting time of $1 \mathrm{~s}$ and their diffractograms recorded. The claystone samples were analysed using a PANalytical X'Pert Pro powder diffractometer with X'Celerator

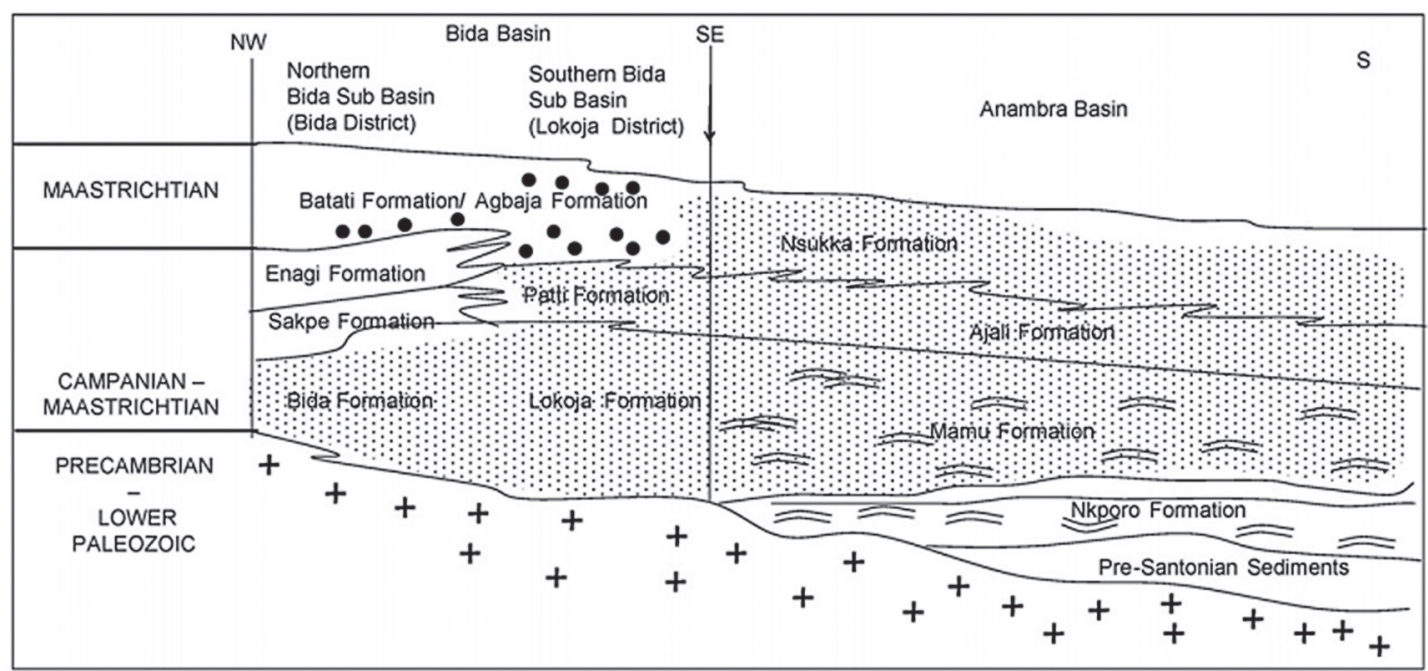

Figure 2. The stratigraphic setting of Bida Basin and correlations with adjacent Anambra Basin (Ojo and Akande, 2009). 
Table 1. Mineralogical composition (wt\%) of Gerinya claystone compared to industrial specifications.

\begin{tabular}{llllllllll}
\hline & Anatase & Diopside & Geothite & Hematite & Kaolinite & Microcline & Muscovite & Quartz & Rutile \\
\hline GER 1C & 0 & 0.7 & 0 & 0.8 & 10.8 & 2.6 & 1.8 & 83.4 & 0 \\
GER 1D & 3.8 & 0 & 0 & 0 & 57.2 & 0 & 2.7 & 35.5 & 0.8 \\
GER 1G & 0 & 0 & 5.9 & 1.1 & 13.7 & 0 & 0 & 78.3 & 0.9 \\
GER 1J & 4.9 & 2.8 & 0 & 0 & 67.6 & 0 & 2.7 & 21.2 & 0.9 \\
GER 1L & 4.4 & 0 & 0 & 0 & 48.6 & 5.7 & 2.2 & 39.3 & 0 \\
GER 1Q & 4.6 & 0 & 0 & 0 & 62.9 & 0 & 2.1 & 30.5 & 0 \\
GER 1S & 5.2 & 0 & 0 & 0 & 22.3 & 3.1 & 3.9 & 64.9 & 0.6 \\
GER 1U & 3.2 & 0 & 0 & 0 & 51.8 & 6.1 & 3.8 & 34.2 & 1.0 \\
Mean & 4.3 & 1.7 & 5.9 & 1.0 & 41.9 & 4.4 & 2.7 & 48.4 & 0.8 \\
Range & $0-5.2$ & $0-2.8$ & $0-5.9$ & $0-1.1$ & $10.8-67.6$ & $0-6.1$ & $0-3.9$ & $21.2-83.4$ & $0-1.0$ \\
STD DEV & 2.1 & 1.0 & 2.1 & 0.5 & 22.7 & 2.6 & 1.23 & 23.6 & 0.5 \\
\hline
\end{tabular}

detector and variable divergence and receiving slits with Fe filtered Co-K $\alpha$ radiation $(\lambda=1.789)$. The phases were recognized using $X^{\prime}$ Pert Highscore plus software. The relative phase amount (weight \%) was assessed using the Rietveld method (Autoquan Program). Amorphous phases, if present were not taken into consideration in the quantification. The percentage mineralogical content was also evaluated based on the relative peak concentrations of the respective minerals in the XRD charts. However, mineral names may not reflect the actual compositions of minerals identified, but rather the mineral group (i.e "Hedenbergite" and "Diopside" would represent the mineral group "Pyroxene").

\section{Results}

\subsection{Lithology description}

The Gerinya exposure is about $1700 \mathrm{~cm}(17.00 \mathrm{~m})$ thick (Fig. 3a and b). At the base of the outcrop is a medium to coarse grained, parallel stratified, sandstone bed, which was overlain by a wavy to parallel laminated siltstone beds. The wavy to parallel laminated siltstone beds evolved into a wavy parallel laminated, brownish to grey silty claystone bed with concretion ironstones. These beds were subsequently overlain by a concretion ironstone bed of about $20 \mathrm{~cm}$. The concretion ironstone evolved into a wavy parallel laminated, brownish to grey silty claystone bed. Succeeding the claystone bed is a sandy claystone bed of about $40 \mathrm{~cm}$, which evolved to a concretional ironstone. The concretional ironstone bed was subsequently overlain by a greyish claystone bed.

The greyish claystone bed is bounded at the top by a concretional, laminated ferruginous claystone that was subsequently overlain by a greyish claystone bed of about $100 \mathrm{~cm}$. Above the greyish claystone bed is a concretional, ferruginous laminated claystone bed that was succeeded by a concretional laminated claystone. Sub- sequently, a grayish shaly claystone bed of about $17 \mathrm{~cm}$ was logged above the concretional laminated claystone. A massive grey claystone bed followed and was succeeded by laminated ferruginous claystone. Thereafter, a thin greyish claystone bed overlain by a laminated concretional ironstone followed. The youngest bed in the study is a ferruginous concretional claystone bed. An overburden of about $100 \mathrm{~cm}$ was observed to be capping this exposure (Fig. 3a).

\subsection{Mineral composition}

A summary of the semi quantitative results of the eight (8) claystone samples (GER 1C, 1D, 1G, 1J, 1L, 1Q, 1S and $1 \mathrm{U}$ ) from the study area are presented in Table 1. Two representative diffractograms were selected from the XRD analysis (Fig. 4). Kaolinite was the dominant clay mineral in the studied claystone with percentage composition ranging from 10.8 to $67.6 \mathrm{wt} \%$ (Table 1). The non-clay minerals present in the claystone samples include quartz, muscovite, anatase, microcline, rutile, diopside, goethite and hematite. Quartz was relatively abundant in all the claystone samples (GER 1C, 1D, 1G, $1 \mathrm{~J}, 1 \mathrm{~L}, 1 \mathrm{Q}, 1 \mathrm{~S}$ and $1 \mathrm{U}$ ) with percentage compositions ranging from 21.2 to $83.4 \mathrm{wt} \%$. Muscovite was present in the analysed claystone samples with percentage compositions ranging from 1.8 to $3.9 \mathrm{wt} \%$ except in Sample GER 1C (Table 1). Anatase was detected in samples GER $1 \mathrm{D}, 1 \mathrm{~J}, 1 \mathrm{~L}, 1 \mathrm{Q}, 1 \mathrm{~S}$ and $1 \mathrm{U}$, with percentage composition ranging from 3.2 to $5.2 \mathrm{wt} \%$. Microcline was detected in four (4) claystone samples (GER 1C, 1L, 1S and 1U) with the percentage compositions ranging from 2.6 to $6.1 \mathrm{wt} \%$. Rutile was detected in Samples GER 1D, 1G, 1J, $1 \mathrm{~S}$ and $1 \mathrm{U}$ with relatively low percentage compositions ranging from 0.6 to $1.0 \mathrm{wt} \%$. Diopside, goethite and hematite were observed in minor occurrence in the claystone samples (Table 1).

Quartz and kaolinite cross plot display a significant linear relationship, having a regression coefficient values 
a)

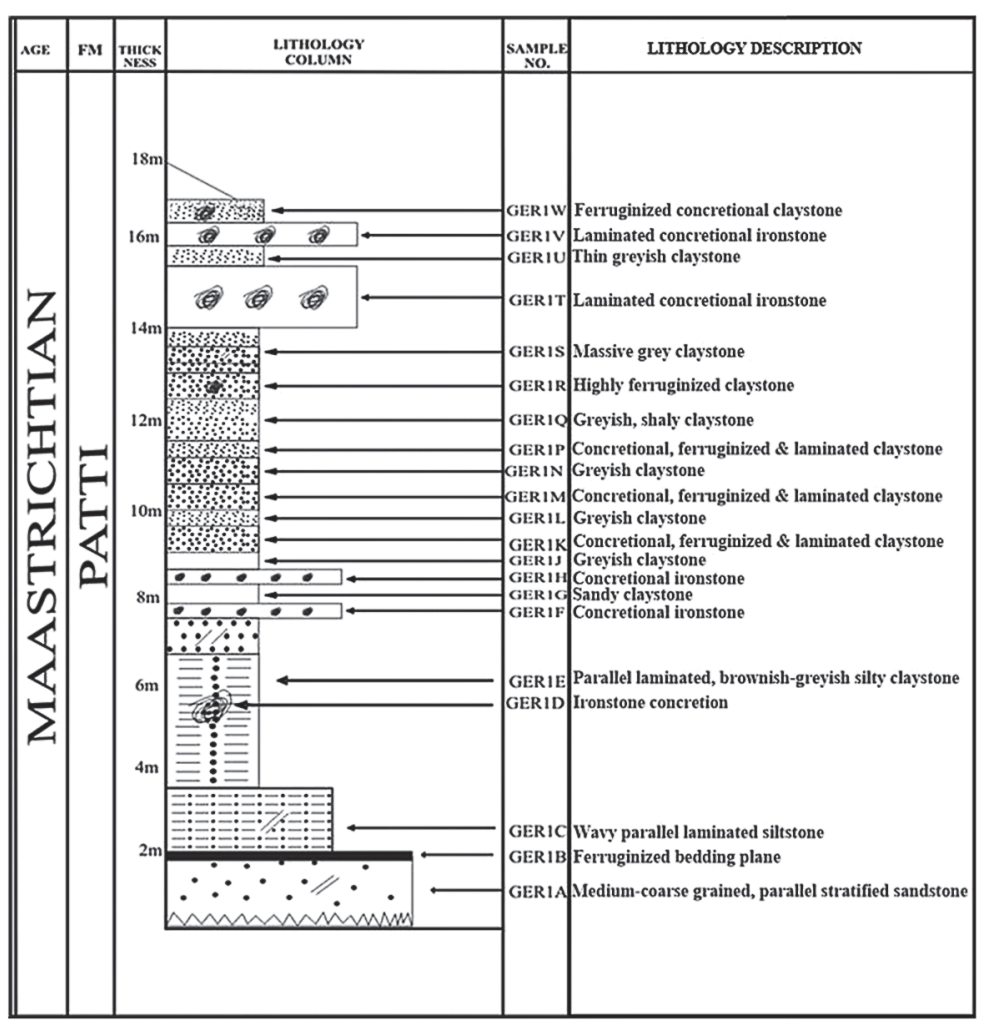

b)

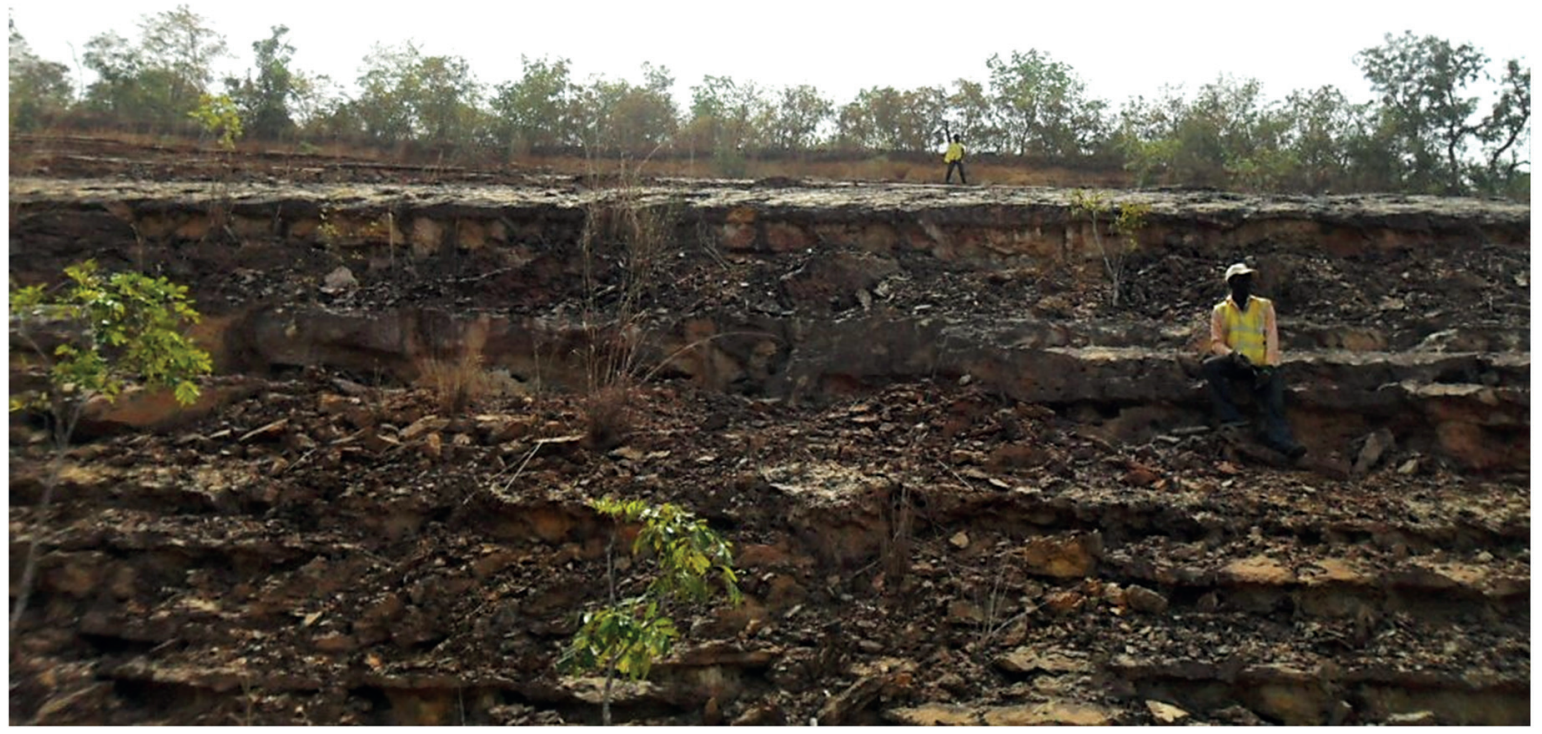

Figure 3. (a) Lithostratigraphic successions of part of the Patti Formation stratigraphic units in Gerinya. (b) An outcrop of the study area.

of 0.983 , with four of the eight samples (GER 1S, 1L, $1 U$ and $1 \mathrm{~J}$ ) falling below the trend line (Fig. 5).

\subsection{Grain size analysis}

A summary of the particle size distribution and the corresponding curve show that the samples contain low amounts of sand-sized particles with mean values ranging from $0.8 \%$ to $5.8 \%$, while the mean value of fines ranged from $94.2 \%$ to $99.2 \%$ (Table 2 ).

\section{Discussion}

\subsection{Mineralogy and provenance}

Based on the identified clay and non-clay minerals in the Geryina Claystone samples (Table 1), the claystones are composed mainly of quartz ( 21 to $83 \%$ ) and kaolinite (10 to $67 \%$ ), that altogether make up $87 \%$ of the whole rock. This kind of mineral assemblage is typical of a hot and humid climate where chemical alteration and hydrolysis of silicate minerals are severe. The occurrence of diop- 
side and felsic minerals (microcline and muscovite) in the same samples (GER 1C and 1J) suggest two source rocks. The first is mafic, ultramafic or metamorphic rocks, while the second is the granitoid rocks where diopside, microcline and muscovite commonly occur. The source area/ sediment provenance can be said to be from both mafic and felsic crystalline rocks that have undergone weathering processes. Muscovite occurs in minor/trace quantities (0$3.9 \mathrm{wt} \%)$ in the analyzed claystone samples which suggest that the claystones were deposited considerably far away from their source area. Samples GER 1C, $1 \mathrm{G}$ and $1 \mathrm{~S}$ are considered to be texturally and mineralogically more matured than the other claystone samples (GER 1D, 1J, $1 \mathrm{~L}, 1 \mathrm{Q}$ and $1 \mathrm{U}$ ) because their quartz contents are above $50 \%$ with low kaolinite, microcline and muscovite percentages (Table 1).

\subsection{Depositional environment}

The major distinct features that characterize the Gerinya claystones are the thin wavy to parallel beds with laminations. The concretional and clay/siltstones intercalation, and kaolinite make up the major clay mineral sediments within the Gerinya claystones, suggesting a low energy floodplain/interchannel environment of deposition. This is supported by the work of Ojo and Akande (2020).

\subsection{Economic potential and industrial usage}

The mineralogy of Gerinya claystone was compared with the mineralogical quantity in other claystones in Nigeria (Table 3). The Gerinya claystone, southern Bida Basin, was compared in Table 3 with claystone in Share, northern Bida Basin (Odewumi, 2013). The content of quartz in the Gerinya claystone is higher than that of the Share Clay, while the kaolinite content is lower than the Share Clay.
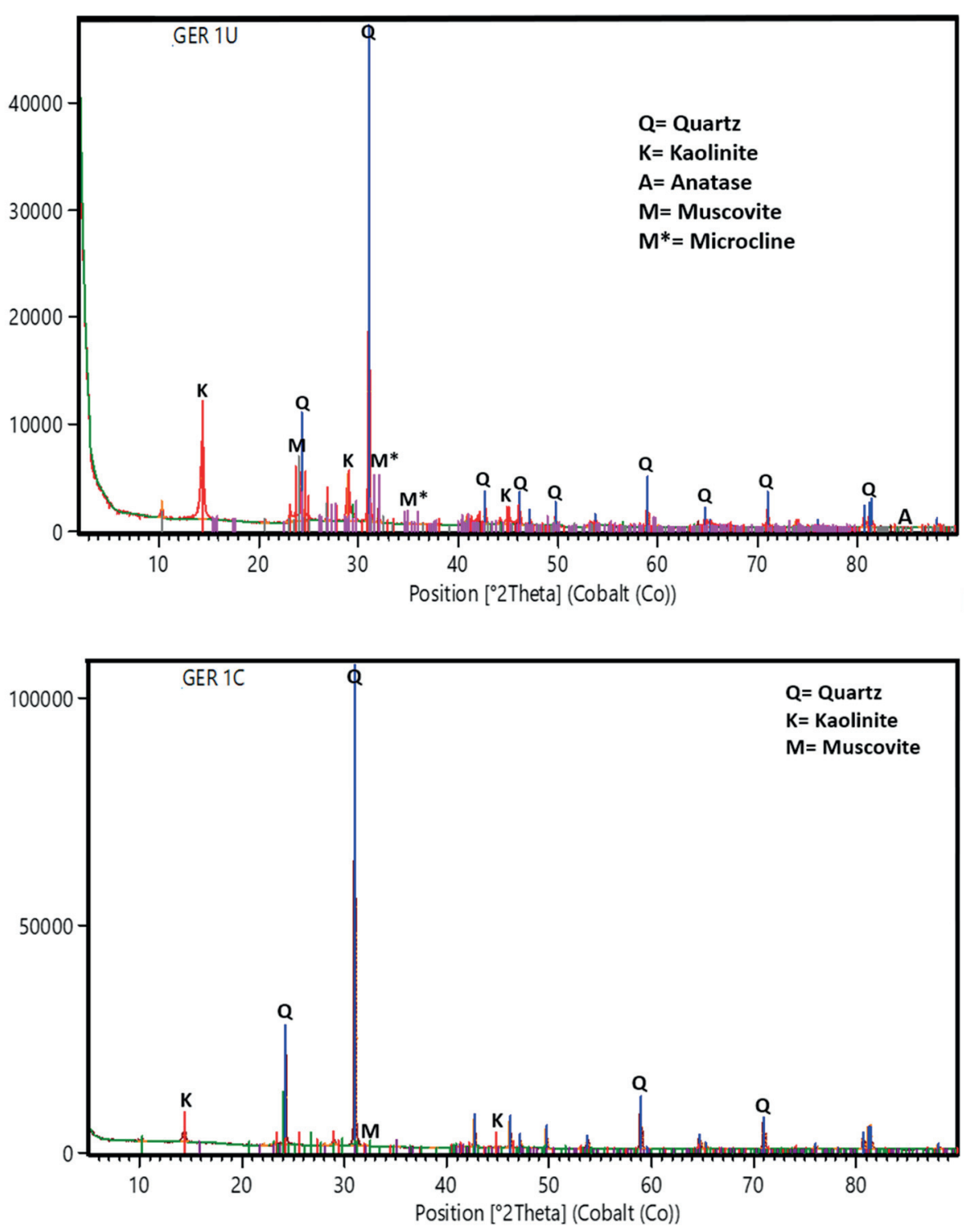

Figure 4. Representative diffractogram of Gerinya claystone (GER $1 \mathrm{C}$ and $1 \mathrm{U}$ ).

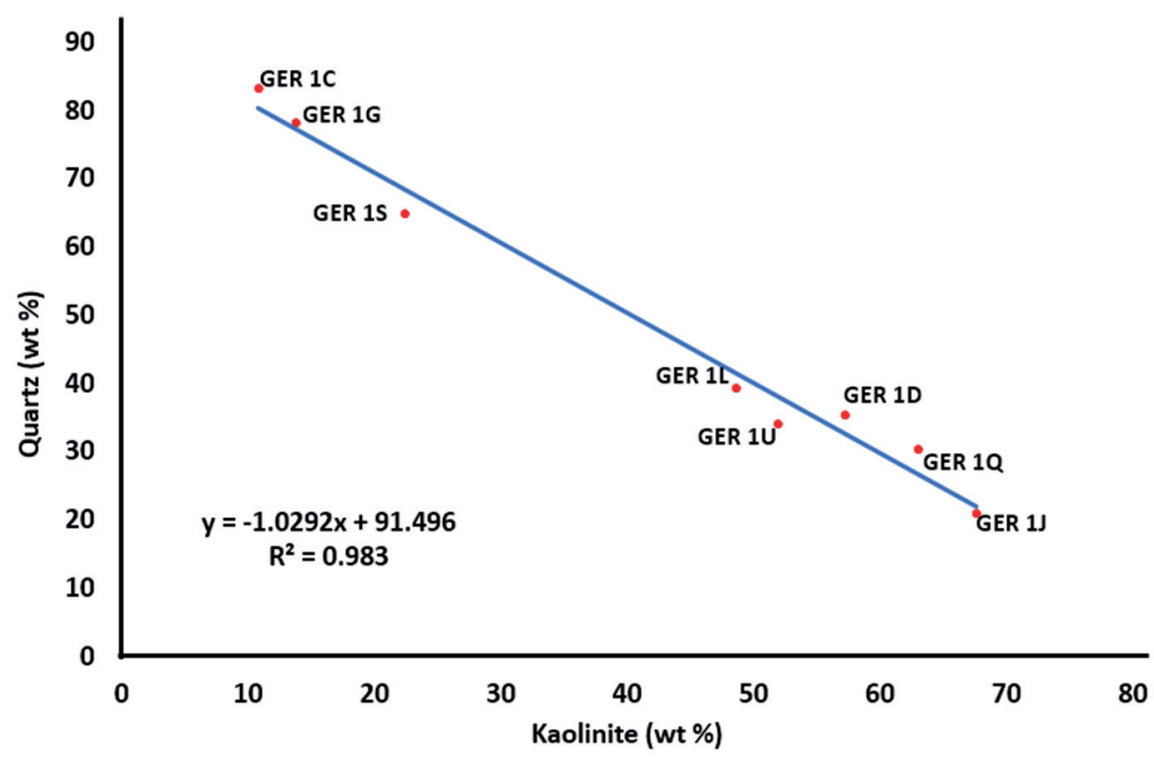

Figure 5. Scatter plot diagram of quartz versus kaolinite of the Gerinya claystone samples. 
Table 2. Particle size distribution of Gerinya claystone samples.

\begin{tabular}{lllll}
\hline & \% Sand & \% Silt & \% Clay & \% Fines \\
\hline GER 1C & 0.8 & 15.2 & 84.0 & 99.2 \\
GER 1D & 3.8 & 10.2 & 86.0 & 96.2 \\
GER 1G & 1.8 & 10.2 & 88.0 & 98.2 \\
GER 1J & 1.8 & 18.2 & 80.0 & 98.2 \\
GER 1L & 4.8 & 15.2 & 80.0 & 95.2 \\
GER 1Q & 5.8 & 25.2 & 69.0 & 94.2 \\
GER 1S & 2.8 & 24.2 & 73.0 & 97.2 \\
GER 1U & 4.8 & 10.2 & 85.0 & 95.2 \\
\hline
\end{tabular}

Table 3. Average mineralogical compositions (wt\%) of Geryina claystones compared with other clays in Nigeria and industrial specifications.

\begin{tabular}{lllllll}
\hline Minerals & GER & SHR & A & B & C & D \\
\hline Quartz & 48.41 & 20.75 & 21.00 & 29.00 & 21.00 & 4.00 \\
Kaolinite & 41.87 & 55.00 & 51.25 & 50.00 & 83.00 & 85.00 \\
Illite & 0.00 & 0.00 & 3.00 & 3.00 & 0.00 & 0.00 \\
Microcline & 2.18 & 0.00 & 3.00 & 9.00 & 0.00 & 3.00 \\
Sepiolite & 0.00 & 0.00 & 12.75 & 6.00 & 0.00 & 0.00 \\
Others & 7.54 & 0.00 & 3.5 & 10.00 & 6.00 & 8.00 \\
\hline
\end{tabular}

GER = Gerinya Claystone. SHR = Share Clay (Odewumi, 2013). A = Asaba and B = Benin Clays (Okunlola and Owoyemi, 2015). C = Eruku and Lakuri Clays (Oyebanjo et al., 2020). D = Nigerian Fertilizer Company of Nigeria (NAFCON, 1985)
The kaolinite content of the Asaba and Benin Clays is higher than that of the Gerinya clastones, but the quartz composition of Gerinya claystone is higher than that of the Asaba and Benin Clays. The kaolinite content of Eruku and Lakuri Clays of the Abeokuta group (Dahomey Basin) is higher than the Gerinya Claystones.

Comparison of the mineralogical composition of Gerinya claystone with the clay content specification suitable for fertiliser production by the Nigerian Fertilizer Company of Nigeria (NAFCON, 1985) revealed that the kaolinite composition of Gerinya claystone is lower than the NAFCON (1985) specification. However, the quartz content of Gerinya claystone is higher than the quartz content of NAFCON (1985). Therefore, the Gerinya claystone will require some processing to be used in fertiliser production.

The only large clay rich sedimentary deposit in China is in the western Guandong Province near Maoming. The massive deposit contains 20 - 25\% kaolinite and 75 $80 \%$ quartz, and are used as raw material for ceramic and as a filler and coating clay for paper (Murray, 2007). The kaolinite composition of the Gerinya claystones is higher than that of the western Guandong Province of China.

The porosity and permeability of the Gerinya claystones were evaluated based on the ternary diagram of McManus (1988). All the Gerinya claystone samples fell within the high porosity and very low permeability quadrant except for Samples GER 1Q and 1S which fell within the

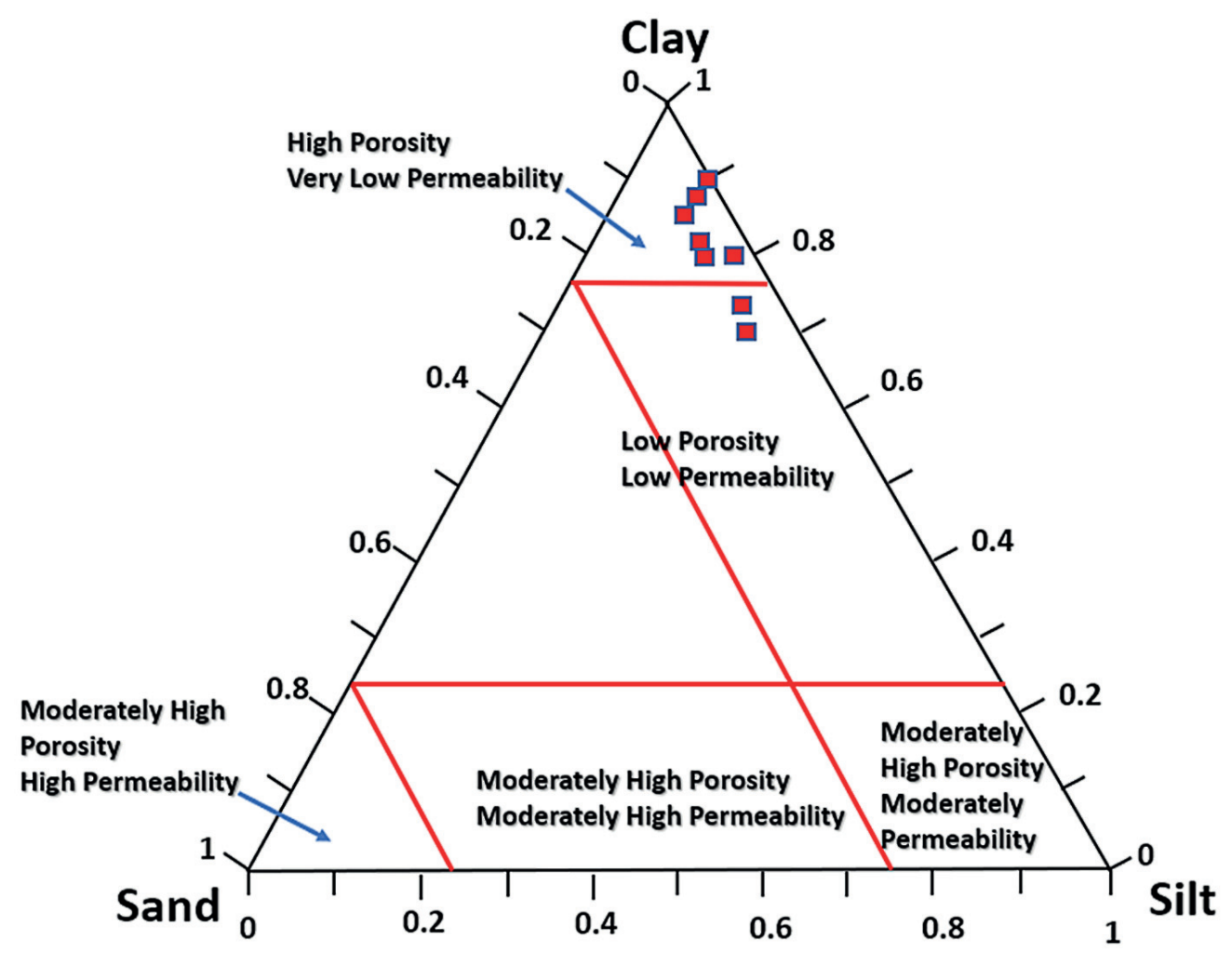

Figure 6. Ternary diagram of Gerinya claystones based on their sand, silt, clay fraction percentages (modified after Oyebanjo et al., 2020). 
low porosity and low permeability regions (Fig. 6). According to Strazzera et al. (1997) and Murray (2007), claystones with high porosity could be used in the production of porous ceramic wares. Very low permeability is a characteristic of low cohesion and strain to extrude, because moderate permeability will facilitate penetration of water into the claystone, increasing the rate of adsorption in the clay.

Daniel (1993) and Benson et al. (1994) proposed that soil liners should have at least $30 \%$ fines and less than $30 \%$ gravel. The Gerinya claystones have fine particle sizes greater than $30 \%$ (Table 2) with low permeability (Fig. 6), making the Gerinya claystones suitable for use as clay liners.

Kaolin (kaolinite, nacrite, gibbsite and dickite) can be utilized to treat diarrhoea, gastritis, colitis, upgrade bio-exercises and preservative of normal intestinal flora. Negative effect may prompt electrolyte disturbance, intestinal blockage, hypertension, peritonitis, eclampsia, iron shortage and microbiological diseases (Geissler, et al., 1998; Kawai, et al., 2009; Odewumi, 2013). The deliberate ingestion/eating of earthy material (geophagia) by both animals and humans, has been documented/ reported in Nigeria, Uganda, South Africa and Swaziland (Abrahams and Parsons, 1997; Ekosse, et al., 2010; Odewumi, 2013). It is most practised among women of childbearing age in the developing countries of Africa (Brand, et al., 2010). The Geryina claystone is rich in kaolinite which is beneficial to human health. However, direct ingestion of the Geryina claystone by humans is harmful because it contains a considerable high level of quartz (21 to $83 \%$ ) which could lead to dental damage of any consumer, and possible puncture/perforation of the sigmoid colon in the gastrointestinal tract of geophagic individuals.

Furthermore, Long, et al. (2019) researched composite for haemorrhage control, iron oxide and kaolinite nanocomposite $\left(\mathrm{Fe}_{2} \mathrm{O}_{3}+\right.$ kaolin). This development explores the characteristics/properties of $\mathrm{Fe}_{2} \mathrm{O}_{3}$ and kaolinite to formulate/assemble a composite with excellent wound curing and healing performances. The test showed that there is synergy existing between both kaolinite and $\mathrm{Fe}_{2} \mathrm{O}_{3}$ : the former (kaolinite) absorb fluid to concentrate blood platelets, red blood cells (RBCs), and clotting factors and activates the intrinsic coagulation cascade; whereas the latter facilitate RBC aggregation and clotting. The kaolinite content in the Geryina claystones can be utilized for treatment of wound, as the claystones exhibits high porosity and low permeability properties which would aid fluid absorption and clotting factor. The Gerinya clastones are therefore suitable for use in the development of haemorrhage control composite, thereby reducing the mortality rate due to haemorrhage.

\section{Conclusions}

The study concluded that the clay mineral in the Gerinya claystones is kaolinite, and the non-clay minerals are quartz, anatase, diopside, goethite, hematite, rutile, muscovite and microcline. The claystones formation is typical of a hot and humid climate where chemical alteration and hydrolysis of silicate minerals are severe. The source area/sediment provenance of the Gerinya claystone are inferred to be from both mafic and felsic crystalline rocks and they are deposited considerably far away from their source area. The Gerinya claystone are inferred to be of low energy floodplain/interchannel environment of deposition. The quartz content of the Gerinya claystones is relatively higher than that of the Share, Asaba and Benin clays, hence recommended for use as ceramic raw material, as a filler and coating clay for paper as well as liners (landfill or composite). The Geryina claystone is rich in kaolinite which is beneficial to human health and suitable for use in the development of haemorrhage control composite, thereby reducing the mortality rate due to haemorrhage. However, direct ingestion of the claystone has harmful effects such as dental damage and possible puncture/perforation of the sigmoid colon in the gastrointestinal tract of geophagic individuals. The harmful nature of the Gerinya claystone is due to the high level of quartz (21 to $83 \%$ ).

\section{Acknowledgements}

The authors are grateful to the anonymous reviewers whose comments and suggestions have substantially contributed to the quality of the manuscripts.

\section{References}

Abrahams, P.W., \& Parsons, J.A. (1997). Geophagy in the tropic: an appraisal of three geophagic materials. Environmental Geochemistry and Health, 19, 19-22.

Aldega, L., Bigi, S., Carminati, E., Trippetta, F., Corrado, S., \& Kavoosi, M.A. (2018). The zagros foldand- thrust belt in the fars province (Iran): II. thermal evolution. Marine and Petroleum Geology, 93, 376-390.

Aldega, L., Carminati, E., Scharf, A., Mattern, F., \& Al-Wardi, M. (2017). Estimating original thickness and extent of the semail ophiolite in the eastern Oman Mountains by paleothermal indicators. Marine and Petroleum Geology, 84, 18-33.

Benson, C.H., Zhai, H., \& Wang, X. (1994). Estimating hydraulic conductivity of clay liners. Journal of Geotechnical Engineering, ASCE, 2, 366-387.

Brand, C.E., De Jager, L., \& Ekosse, G.E. (2010). Possible health effects associated with human geophagic practice: an overview. South African Medical Technology, 1, 11-13. doi/10.10520/EJC74222.

Corrado, S., Aldega, L., Celano, A.S., De Benedetti, A.A., \& Giordano, G. (2014). Cap rock efficiency and fluid circulation of natural hydrothermal systems by means of 
XRD on clay minerals (Sutri, Northern Latium, Italy). Geothermics, 50, 180-188.

Cox , M.E. \& Brown, P. (1998). Hydrothermal alteration mineralogy as an indicator of hidrology at the Ngahwa geothermal field, New Zealand. Geothermics, 27, 259-270.

Daniel, D.E. (1993). Clay liners. In: Geotechnical Practice for Waste Disposal, (ed. David E. Daniel) Chapman \& Hall, London, UK, 137-163. doi/10.1007/978-1-4615-30701.

Ekosse, G.E., De Jager, L., \& Ngole, V.M. (2010). Traditional mining and mineralogy of geophagic clays from Limpopo and free state provinces, South Africa. African Journal of Biotechnology, 47, 8058-8067.

Geissler, P.W., Mwaniki, D., Thiong'O, F., \& Friis, H. (1998). Geophagy as a risk factor for geohelminth infections: a longitudinal study of Kenyan primary school children. Transactions of the Royal Society of Tropical Medicine and Hygiene, 1, 7-11.

Grand View Research. (2020). Kaolin market size, share and trends analysis report by application (paper, ceramics, paint and coatings, fiber glass, plastic, rubber, cosmetics, pharmaceutical and medical) by region and segment forecasts, 2020 - 2027. report ID: 978-1-68038337-9. (Accessed 22 March 2021)

https://www.grandviewresearch.com/industry-analysis/kaolin-market

Hower, J., Eslinger, E., Hower, M.E., \& Perry, E.A. (1976). Mechanism of burial metamorphism of argillaceous sediment: mineralogical and chemical evidence. Geological Society of America Bulletin, 5, 725-737.

Kawai, K., Saathoff, E., Antelman, G., Msamanga, G., \& Fawzi, W.W. (2009). Geophagy (soil-eating) in relation to anaemia and helminth infection among HIV-infected pregnant women in Tanzania. The American Journal of Tropical Medicine and Hygiene, 1, 36-43.

Long, M., Zhang, B., Peng, S., Liao, J., Zhang, Y., Wang, J., Wang, M., Qin, B., Huang, J., Huang, J., Chen, X., \& Yang, H. (2019). Interactions between two-dimensional nanoclay and blood cells in hemostasis. Materials Science and Engineering C, 105, 110081. doi: 10.1016/j. msec.2019.110081.

Mpuchane, S., Ekosse, G., Gashe, B., Morobe, I., \& Coetzee, S. (2008). Mineralogy of southern African medicinal and cosmetic clays and their effects on the growth of selected test microorganisms. Fresenius Environment Bulletin, 15, 547-557.

Murray, H.H. (2007). Applied Clay Mineralogy. Occurrences, Processing and Application of Kaolins, Bentonites, Palygorskite-Sepiolite, and Common Clays, 1st ed.; Elsevier: Oxford, UK. 189. doi.org/ 978-0-444-51701-2.

National Fertilizer Company of Nigeria (NAFCON), 1985. Tender document for supply of kaolin from Nigeria sources, p 65. In: Akinola, O.O., \& Obasi, R.A. (2014). Compositional characteristics and industrial potential of the lateritic clay deposit in Ara-ljero Ekiti areas, southwestern Nigeria. International Journal of Scientific and Technology Research, 3, 304-311.

Nesbitt, H.W., \& Young, G.M. (1989). Formation and diagenesis of weathering profiles; Journal of Geology, 97, 129-147. doi.org/10.1086/629290.

Obaje, N.G. (2009). Geology and mineral resources of Nigeria. Springer-Verlag Berlin Heidelberg, 221. doi. org/10.1007/978-3-540-92685-6.
Odewumi, S.C. (2013). Mineralogy and geochemistry of geophagic clays from Share area, northern Bida sedimentary basin, Nigeria. African Journal of Natural Science, 16, 87-98.

Ojo, O.J., \& Akande, S.O. (2009). Sedimentology and depositional environments of the Maastrichtian Patti Formation, southeastern Bida Basin, Nigeria. Cretaceous Research, 30, 1415-1425.

Ojo O.J., \& Akande S.O. (2020). A revised stratigraphy of the Bida Basin, Nigeria by Rahaman et al., (2019) [Journal of African Earth Sciences., 151, 67-81]: A rebuttal. Journal of African Earth Sciences, 172, 103983.

Okunlola, O.A., \& Owoyemi, K.A. (2015). Compositional characteristics of geophagic clays of Southern Nigeria. Earth Science Research, 4(2), 10-15.

Olabode, S.O. (2016). Soft sediment deformation structures in the Maastrichtian Patti Formation, southern Bida Basin Nigeria: implications for the assessment of endogenic triggers in the Maastrichtian sedimentary record. Open Journal of Geology, 6, 410-438.

Oyebanjo, O., Ekosse, G., \& Odiyo, J., (2020). Physico-Chemical, Mineralogical, and Chemical Characterisation of Cretaceous-Paleogene/Neogene Kaolins within Eastern Dahomey and Niger Delta Basins from Nigeria: Possible Industrial Applications. Minerals, 10, 670. doi:10.3390/min10080670.

Singh, P. (2009). Major, trace and REE geochemistry of the Ganga River sediments: influence of provenance and sedimentary processes. Chemical Geology, 266, 242255.

Strazzera, B., Dondi, M., \& Marsigli, M. (1997). Composition and ceramic properties of tertiary clays from southern Sardinia (Italy). Applied Clay Science, 12, 247-266.

Velde, B., \& Meunier A. (2008). The origin of clay minerals in soils and weathered rocks. Berlin, Heidelberg: Springer. doi.org/10.1007/978-3-540-75634-7.

Velde, B. (1992). Introduction to Clay Minerals. Dordrecht: Springer. doi.org/10.1007/978-94-011-2368-6.

Velde, B. (1995). Origin and Mineralogy of Clays. Berlin, Heidelberg: Springer. doi.org/10.1007/978-3-662-126486.

Wentworth, C.K. (1922). A scale of grade and class terms for clastic sediments. Journal of Geology, 30, 377-392.

Received: 11 March 2021

Accepted: 20 December 2021

Handling Editors: Marek Michalik, Jarosław Majka 